\title{
Oxidative Stress, Neuroinflammation and Mitochondria in the Pathophysiology of Amyotrophic Lateral Sclerosis
}

\author{
Elena Obrador, Rosario Salvador ${ }^{\mathbb{D}}$, Rafael López-Blanch, Ali Jihad-Jebbar, Soraya L. Vallés and \\ José M. Estrela * \\ Department of Physiology, Faculty of Medicine and Odontology, University of Valencia, 15 Av. Blasco Ibañez, \\ 4601016 Valencia, Spain; elena.obrador@uv.es (E.O.); rosario.salvador@uv.es (R.S.); \\ loblanch@alumni.uv.es (R.L.-B.); aji.jebbar@gmail.com (A.J.-J.); lilian.valles@uv.es (S.L.V.) \\ * Correspondence: jose.m.estrela@uv.es; Tel.: +34-963864646; Fax: +34-963864642
}

Received: 29 August 2020; Accepted: 20 September 2020; Published: 22 September 2020

check for updates

\begin{abstract}
Amyotrophic lateral sclerosis (ALS) is a progressive motor neuron (MN) disease. Its primary cause remains elusive, although a combination of different causal factors cannot be ruled out. There is no cure, and prognosis is poor. Most patients with ALS die due to disease-related complications, such as respiratory failure, within three years of diagnosis. While the underlying mechanisms are unclear, different cell types (microglia, astrocytes, macrophages and $\mathrm{T}$ cell subsets) appear to play key roles in the pathophysiology of the disease. Neuroinflammation and oxidative stress pave the way leading to neurodegeneration and $\mathrm{MN}$ death. ALS-associated mitochondrial dysfunction occurs at different levels, and these organelles are involved in the mechanism of MN death. Molecular and cellular interactions are presented here as a sequential cascade of events. Based on our present knowledge, the discussion leads to the idea that feasible therapeutic strategies should focus in interfering with the pathophysiology of the disease at different steps.
\end{abstract}

Keywords: amyotrophic lateral sclerosis; motor neuron disease; neuroinflammation; oxidative stress; mitochondria

\section{Introduction}

Amyotrophic lateral sclerosis (ALS), the most common motor neuron (MN) disease, is considered a rare disease based on its prevalence (2-3 cases per 100,000 people with European ancestry). The mean age of onset is 50-65 years, with only $5 \%$ of cases manifesting at 30 years or younger. In the younger patients, male predominate [1]. Mean survival from the first symptom is $3-5$ years, although about $10 \%$ of patients live longer than 10 years [2].

The cause is unknown in $90-95 \%$ of all cases (sporadic ALS (SALS)), and just $5-10 \%$ of cases are associated with known genetic mutations (familial-type ALS (FALS)) [3]. More than 30 different genes have been linked to FALS [4]. However, the most common mutations are found in C9orf72, SOD1, FUS, or TARDBP. These represent approximately $40 \%, 20 \%, 1-5 \%$, and $2-5 \%$ of FALS cases, respectively [5].

In the absence of a family history of the disease, there is no known cause of ALS. Nevertheless, the involvement of many possible causal/risk factors has been suggested. This includes (but not limited to) chemicals, metals, radiation/electromagnetic fields, physical activity, dietary habits, viruses, bacteria, prions, fungi, protein-related abnormalities, mitochondria-related pathology, glutamate excitotoxicity, higher energy expenditure than intake and progressive impairment of glucose metabolism, microtubule mediated deficits in axonal transport, reactive phenotypes in astrocytes and microglia, autoimmunity, and moderate to severe traumatic brain injury $[3,6-14]$ 
ALS is characterized by the progressive degeneration of cortical, brainstem, and spinal MNs. The region initially affected is typically within the upper limb, lower limb or bulbar musculature, however the subsequent progression is highly variable. Limb-onset is predominant ( $70 \%$ of all cases) and is associated with the death of upper MNs (UMNs) in the brain, and lower MNs (LMNs) in the brain stem and spinal cord. Bulbar-onset ( $25 \%$ of all cases) first affects the muscles in the face, mouth, and throat since MNs in the brain stem start to die first along with other LMNs. In the remaining $5 \%$ of all cases muscles in the trunk of the body are affected first. Yet many patients, even in late stages, can still move their eyes and sometimes control the sphincter and a few other muscles. Thus suggesting that some MNs are more vulnerable than others [15].

Common symptoms include muscle weakness, twitching, and cramping, leading eventually to muscle impairment. In the most advanced stages, patients will develop symptoms of dyspnea and dysphagia. Most patients die from respiratory failure [16].

The underlying mechanisms, as well as the cause or causes, of this devastating disease remain largely unknown. Consequently, ALS is designated by the FDA as an orphan disease.

\section{Neuroinflammation and Oxidative Stress}

Neuroinflammation, characterized by the presence of reactive astrocytes and microglia, moderate infiltration of peripheral immune cells, as well as elevated levels of inflammatory mediators, affects motor regions of the central nervous system (CNS) in SALS and FALS [17]. Microglia represents the primary form of active immune defense in the CNS [18]. If these cells cannot eliminate a toxic insult, they remain reactive and continue to recruit astrocytes and oligodendrocytes causing an ongoing inflammatory process [19]. In ALS patients and animal models, the abnormal proliferation of astrocytes (astrogliosis) that surrounds the degenerating MNs has been observed [20]. Reactive astrocytes in ALS express inflammatory markers, including cyclo-oxygenase-2, inducible NOS, and neuronal NOS [20], and inhibitory molecules that block regrowth of a damaged axon [21]. Moreover, astrocytes derived from the spinal cord of SALS or FALS patients have been shown cytotoxic to MNs in culture [22]. Furthermore, in mouse models of ALS, mast cells and neutrophils have been shown to accumulate around motor axons in the extensor digitorum longus muscle, sciatic nerve, and ventral roots, indicating that immune cell infiltration has far-reaching consequences along the entire peripheral motor pathway [23].

Remarkably, aberrant glial cells exhibit exacerbated endoplasmic reticulum stress together with a significant abundance of autophagic and secretory vesicles, all characteristic features of cellular stress and inflammatory activation. Activated microglia release proinflammatory cytokines (e.g., TNF $\alpha$, IL1 $\beta$, IL12, IFN $\gamma$ ), mitogenic factors (e.g., MCP-1, M-CSF), neurotrophic factors (e.g., IGF-1), and anti-inflammatory factors (e.g., TGF- $\beta$ ) [24], all of which may exert a neurotoxic effect on the MNs. Cytokines secreted by activated microglia, including IL1 $\alpha$, TNF $\alpha$ and C1q, have been shown to further induce the A1 subtype of reactive astrocytes (key in neuronal death in neurodegenerative diseases including ALS) [25]. Moreover, the levels of different cytokines, such as G-CSF, IL2, IL15, IL17, MCP-1, MIP1 $\alpha, \mathrm{TNF} \alpha$, and VEGF, have been identified in abnormally high levels in the cerebrospinal fluid (CSF) of patients with ALS [26]. Moreover, IL-6 levels in astrocyte-derived exosomes were also found increased in SALS patients, thus suggesting that CNS-derived exosomes could be useful to reveal neuroinflammation of the CNS in ALS patients and positively associated with the rate of disease progression [27]. All these phenomena further implicate neuroinflammatory processes in the pathogenesis of ALS. Importantly, recent data demonstrate that neuroinflammation is linked to the symptomatic phase of ALS/FTD (frontotemporal dementia) and shows a similar pattern in sporadic and genetic cases. ALS and FTD are characterized by a different neuroinflammatory profile, which might be one driver of the diverse presentations of the ALS/FTD syndrome [28].

In spite of the mounting evidence uniting neuroinflammatory processes and neuronal death in ALS, the immune system appears to be protective during the early stages of the disease. Glia and T cells, especially M2 macrophages/microglia, and T helper (Th) 2 cells and regulatory T (Treg) cells are 
key anti-inflammatory factors that sustain MN viability. However, as the disease progresses and $\mathrm{MN}$ injury accelerates, a second rapidly-progressing phase develops, that is characterized by increased levels of M1 macrophages/microglia, and proinflammatory Th1 and Th17 T cells [29]. It has been suggested that the neuroprotective M2/Treg/Th2-mediated pathways are downregulated whereas the cytotoxic M1/Th1/Th17 pathways are upregulated, resulting in a self-propagating proinflammatory acceleration of disease progression [30-34].

Neuroinflammation and oxidative stress (OS) are inextricably linked in the pathogenesis of neurodegenerative diseases. OS is the consequence of increased production of reactive oxygen species (ROS), which is frequently accompanied by a decrease in antioxidant defenses [35]. Glial and infiltrated immune cells are considered among the major producers of ROS and reactive nitrogen species (RNS) in pathological conditions of the CNS [36]. Although ROS are not believed to cause ALS, they are likely to exacerbate disease progression [17].

OS may also contribute to the degeneration of the neuromuscular junction in ALS. Increased sensitivity of the nerve terminal to ROS has been shown in ALS mouse models, which may facilitate presynaptic decline in neuromuscular junctions. Moreover, excitatory amino acid-mediated overstimulation of MNs results in abnormal secretion of acetylcholinesterase, which will decrease the acetylcholine present in the synaptic cleft (a mechanism that could be behind the loss of muscle strength observed in ALS patients). These early-stage dysfunctions are accompanied by inflammatory agents and loss of trophic support, which ultimately may lead to neurodegeneration [37].

There is also evidence that the response to OS is dampened in ALS. Levels of glutathione (GSH), a prevalent antioxidant in mammalian cells, are lower in the motor cortex of ALS patients as compared to healthy volunteers [38,39]. Moreover, expression of mutant TDP-43 in a MN-like cell line induces OS and mitochondrial damage eliciting nuclear accumulation of nuclear factor E2-related factor 2 (Nrf2), a master regulator of detoxification and also of antioxidant, anti-inflammatory and other cytoprotective mechanisms [40,41]. Dysregulated Nrf2-dependent antioxidant pathways have been implicated in ALS, and therapeutic strategies targeting the Nrf2 antioxidant response element are under investigation [42]. Nrf2 mRNA and protein levels are depleted in post-mortem tissues from ALS patients [42], and studies in ALS mouse models have shown a significant beneficial effect of elevated Nrf2 levels in astrocytes, the major GSH suppliers for neighboring neurons [43], Furthermore, Nrf2 signaling is critical for attenuating neuroinflammation in ALS through repression of the deleterious effects of activated microglia on neurons [44].

From all this evidence, we can conclude that neuroinflammation and OS are intertwined mechanisms involved in the physiopathology of ALS.

\section{Mitochondria and the Mechanism of Motor Neuron Death}

Mitochondrial dysfunction has also been implicated as a key neuropathological hallmark of ALS [12]. For instance, reduction of the activity of the electron transport chain complexes (complex I-IV) in post-mortem spinal cord specimens from SALS patients [45], reduced intracellular ATP levels in lymphocytes of ALS patients [46], or inhibition of the voltage-dependent anion channel (VDAC) by mutant SOD1 [47].

The class III deacetylases, or sirtuins (SIRT), are a family of conserved epigenetic mediators that regulate a myriad of cellular processes relating to health- and life-span. Three of the seven known SIRT (SIRT3, SIRT4 and SIRT5) are primarily localized to the mitochondria [48].

SIRT3 has been extensively studied for its role in energy homeostasis. In addition to deacetylating and regulating several mitochondrial enzymes (such as acetyl-CoA synthase 2 and glutamate dehydrogenase, SIRT3 has been shown to regulate the production of mitochondrial ROS [49].

SIRT1 is primarily nuclear and has been shown to regulate longevity by maintaining mitochondrial homeostasis and mitophagy. Interestingly, intraperitoneal injection (but not oral administration) of resveratrol, a potential SIRT1 activator, led to a significant improvement in both symptoms and survival in the SOD1 ${ }^{\mathrm{G} 93 \mathrm{~A}}$ mouse model of ALS [50]. This is consistent with recent findings where 
overexpression of SIRT1 in MN of SOD1 ${ }^{\mathrm{G} 93 \mathrm{~A}}$ mice delays the onset of the disease and increases survival [51]. Moreover, SIRT1 may have wide-reaching implications on mitochondrial biogenesis via the deacetylation of PGC-1 $\alpha$ [52]. PGC- $1 \alpha$ is downregulated in SALS patients [53]. A decrease in PGC- $1 \alpha$ associates with lower expression of SIRT3, a regulator of mitochondrial energy metabolism and ROS that is regulated by PGC-1 $\alpha$ [54]. Overexpression of SIRT3 in cultured cells increases respiration and PGC- $1 \alpha$ expression, and decreases the production of ROS [54,55]. Furthermore, overexpression of SIRT3 and PGC- $1 \alpha$ protects against mitochondrial fragmentation and death in SOD1 ${ }^{\mathrm{G} 93 \mathrm{~A}}$ MNs [54]. Moreover, SIRT3 deficiency results in hyperacetylation of SOD2 and cyclophilin $\mathrm{D}$, two mitochondrial proteins involved in regulating adaptive responses of neurons to physiological challenges and resistance to degeneration. SIRT3 was also shown to regulate ketone body production by deacetylating mitochondrial 3-hydroxy-3-methylglutaryl CoA synthase 2. This evidence is consistent with the elevation of mitochondrial SIRT3 expression in medium chain triglyceride-treated primary MN cultures and in the spinal cord of SOD1 ${ }^{\mathrm{G} 93 \mathrm{~A}}$ mice following medium chain triglyceride treatment [56]. The authors hypothesize that medium chain triglycerides might regulate mitochondrial activity and cell survival through sirtuin-mediated responses.

Consumption of $\mathrm{NAD}^{+}$without an adequate method of replenishment can result in decreased activity of SIRT-dependent processes, and a consequential deleterious effect on mitochondrial biogenesis, function and mitophagy [48]. Thus, SIRT deactivation may contribute to the mitochondrial dysfunction associated with ALS. Indeed, it has been shown that methods to enhance $\mathrm{NAD}^{+}$salvage pathways were able to attenuate the neurotoxic phenotype of SOD1 ${ }^{\mathrm{G} 93 \mathrm{~A}}$ astrocytes; this observation was most likely due to increased SIRT1 and SIRT3 activities associated with greater NAD ${ }^{+}$availability [57]. Thus, methods to increase SIRT activity, by restoring $\mathrm{NAD}^{+}$levels or via direct activation using small molecules, are potential therapeutic approaches in the treatment of ALS.

A recent human pilot study [58], demonstrating that the experimental therapeutic EH301 may be able to slow the progressive decline in functionality, strength and lung function, may offer new insight into the pathophysiology underpinning ALS. EH301 is a combination of nicotinamide riboside (NR) and pterostilbene (PT); compounds that are predicted to increase availability of the coenzyme NAD ${ }^{+}$ and support the activity of the SIRT and their downstream targets.

$\mathrm{NR}$, a pyridine-nucleoside form of vitamin $\mathrm{B} 3$, is a precursor to $\mathrm{NAD}^{+}$with superior pharmacokinetic profile relative to other forms of $B 3$ (nicotinic acid and nicotinamide) [59]. Since $\mathrm{NAD}^{+}$depletion associates with neuronal death [60], it has been proposed that increasing $\mathrm{NAD}^{+}$ availability may be neuroprotective [61]. Gerdts et al. demonstrated, using a model of sterile alpha and TIR motif-constraining 1 (SARM1)-induced axonal death, that $\mathrm{NAD}^{+}$levels are rapidly depleted following axonal injury [62]. Treatment with NR was shown to prevent axonal degeneration and cell death in this model.

Additionally, two modes of operation by isolated mitochondria result in significant $\mathrm{O}_{2}{ }^{\bullet-}$ production, predominantly from complex I: (i) when the mitochondria are not making ATP and consequently have a high $\Delta \mathrm{p}$ (protonmotive force) and a reduced CoQ (coenzyme Q) pool; and (ii) when there is a high $\mathrm{NADH} / \mathrm{NAD}^{+}$ratio in the mitochondrial matrix. For mitochondria that are actively making ATP, and consequently have a lower $\triangle \mathrm{p}$ and NADH/NAD $\mathrm{Natio}^{+}$, the extent of $\mathrm{O}_{2}{ }^{\bullet-}$ production is far lower [63]. $\mathrm{NAD}^{+}$-derived nicotinamide suppresses $\mathrm{O}_{2}{ }^{\bullet-}$ generation via reduction of electron transport and increases membrane potential $(\Delta \psi \mathrm{m})$ via downregulation of mitochondrial permeability transition pore (mtPTP) formation [64].

PT (3,5-dimethoxy-4'-hydroxystilbene) is a naturally occurring stilbenoid, found primarily in blueberries and Pterocarpus marsupium heartwood. PT is a dimethylated analogue of resveratrol; a SIRT1-activating molecule that has been shown to increase lifespan in different model organisms [65]. Han et al. reported delayed disease onset and increased survival in resveratrol-treated SOD1G93A mice [50]. The authors suggested that the therapeutic benefits of resveratrol may be due to increased SIRT1 activation, which was measured via deacetylation of p53 (a major SIRT1 substrate). Mancuso et al. and Song et al. also reported delayed disease onset, extended survival and improved spinal 
motor neuron function in SOD1 ${ }^{\mathrm{G} 93 \mathrm{~A}}$ mice, and both authors noted increased SIRT1 activation in the spinal cord [66,67]. However the low bioavailability of this polyphenol has limited its translation into the clinical setting [65]. PT substitutes two hydroxyl groups in resveratrol for methoxy groups, modifications that increase PT's lipophicity and half-life. PT can cross the blood brain barrier and has been shown to increase nuclear Nrf2, thus potentially promoting the antioxidant defenses in the CNS [68]. Interestingly, PT has also been shown to attenuate early brain injury following subarachnoid hemorrhage via inhibition of the nucleotide-binding oligomerization domain-like receptor family pyrin domain-containing 3 (NLRP3) inflammasome and NOX2-related OS [69]. Which may further support the therapeutic role of PT in ALS, since the microglial NLRP3 inflammasome is activated by ALS proteins [70].

Figure 1 displays an integrated scheme of the molecular interactions underlying the potential benefits exerted by the combination of NR and PT. mtGSH depletion (either by oxidation or by inhibition of its transport) can promote the release of proapoptotic signals to the cytosol [71]. In this regard Mytilineou et al. provided evidence that neuronal GSH depletion in the presence of glial cells leads to neuronal degeneration [72].

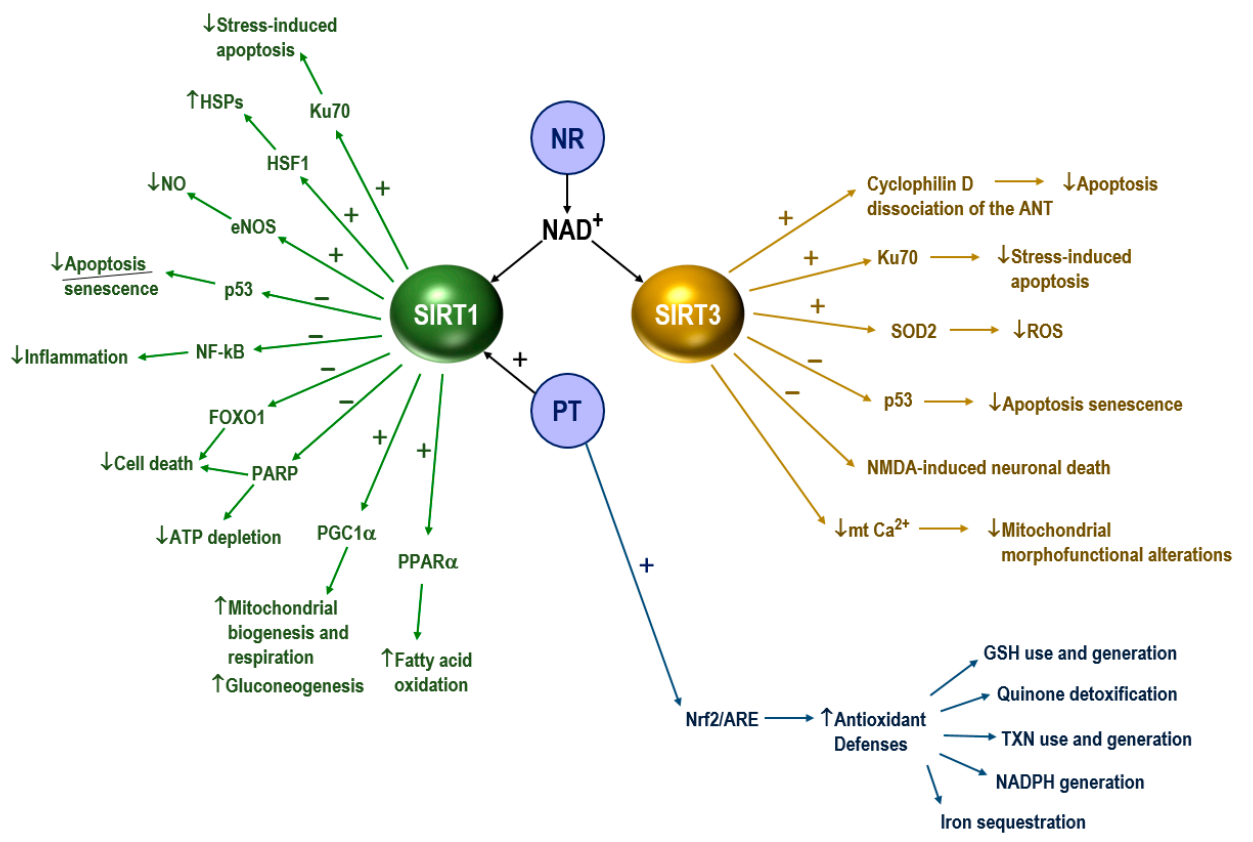

Figure 1. Molecular interactions underlying the effect of nicotinamide riboside (NR) and pterostilbene (PT) in amyotrophic lateral sclerosis (ALS). SIRT1, sirtuin 1; SIRT3, sirtuin 3; HSPs, heat-shock proteins; HSF1, heat-shock factor 1; NF-kB, nuclear factor kappa-light-chain-enhancer of activated B cells; FOXO1, forkhead box protein O1; PARP, poly (ADP-ribose) polymerase; PGC1 $\alpha$, peroxisome proliferator-activated receptor gamma coactivator 1-alpha; LXRs, liver X receptors; eNOS endothelial nitric oxide synthase; $\operatorname{PPAR} \alpha$, peroxisome proliferator-activated receptors alpha; Nrf2/ARE, transcription factor Nrf2 (NF-E2-related factor 2)/antioxidant responsive element; ANT, adenine nucleotide translocator; SOD2, superoxide dismutase 2; NMDA, N-metil-D-aspartato; GSH, glutathione; TXN, thioredoxin. NR increases the availability of $\mathrm{NAD}^{+}$, which supports the activity of SIRT1 and SIRT3 and their downstream targets. PT activates SIRT1 and Nrf2. Activation of Nrf2 in MNs results in the induction of many cytoprotective proteins, i.e., (but are not limited to) the following: (1) GSH use and generation ( $\gamma$-glutamyl-cysteine synthase, GSH reductase, $x \mathrm{CT}$ (a component of the cysteine/glutamate transporter), GSH peroxidase 2, different GSH transferase isoenzymes); (2) quinone detoxification $(\mathrm{NAD}(\mathrm{P}) \mathrm{H}$ dehydrogenase (quinone 1)); (3) thioredoxin use and generation (thioredoxin 1 , peroxiredoxin 1 , thioredoxin reductase 1); (4) iron sequestration (heme oxygenase 2); (5) NADPH generation (glucose-6-P dehydrogenase, phosphogluconate dehydrogenase, malic enzyme 1, isocitrate dehydrogenase 1) $[42,65,73-79]$. 
The role of the adenine nucleotide translocator (ANT) in apoptosis is well known [80] and, as part of the mechanisms linking apoptosis and ALS, the mtPTP has been implicated in the pathogenesis [81]. The ANT forms the inner membrane channel of the mtPTP complex [82]. In vitro cell experiments have shown that $\mathrm{NO}$ and $\mathrm{ONOO}^{-}$can act directly on the ANT to induce mitochondrial permeabilization [83]. Interestingly the ANT and its regulator (cyclophiline D, CyPD) were found as targets of nitration in ALS mice [84]. SOD1 ${ }^{\text {G93A }}$ mice without CyPD (genetic ablation of the Ppif gene) showed markedly delayed disease onset and lived significantly longer than mice with CyPD [84]. In ALS patients affected anterior horns of the spinal cord are depleted of large $\mathrm{MN}$, whereas the remaining $\mathrm{MN}$ are partially atrophic [81]. Cell death assays identified subsets of $\mathrm{MN}$ in the process of DNA fragmentation as the nucleus condenses and the cell body shrinks [81]. Moreover, in ALS patients, p53 (which promotes apoptosis via the Apaf-1/caspase-9 pathway and involves mitochondrial cytochrome c release) [85], accumulates in the nucleus of $\mathrm{MN}$. Based on these observations and related background a plausible model of the mechanism leading to apoptotic cell death in $\mathrm{MN}$ is displayed in Figure 2.
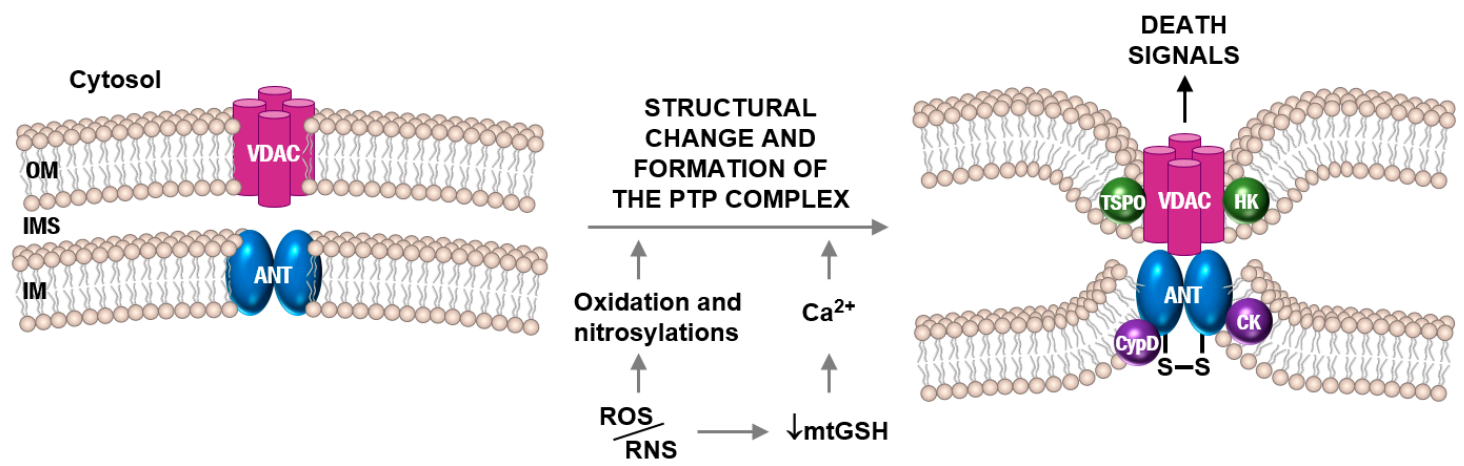

Figure 2. Opening of the mtPTP complex preceding apoptotic motor neuron death during ALS pathophysiology. The voltage-dependent anion channel (VDAC) and mitochondrial adenine nucleotide translocator (ANT) are both dimers located in the outer and inner membranes, respectively. High membrane potential in normally functioning mitochondria keeps the mitochondrial permeability transition pore (mtPTP) closed. Under pathophysiological conditions such as oxidative/nitrosative stress, the mtPTP opens, allowing the entry of $\mathrm{H}_{2} \mathrm{O}$ and solutes. Thus, causing mitochondrial swelling and release of apoptosis-initiating factor (AIF) and cytochrome c from the intermembrane space (IMS), which ultimately results in apoptosis. ROS/RNS cause mtGSH depletion and, consequently, higher levels of intramitochondrial free $\mathrm{Ca}^{2+}$, oxidation of critical redox-sensitive -SH groups of the ANT (e.g., Cys56; which, under physiological conditions, are in equilibrium with matrix GSH), and decreased mitochondrial membrane potential. All these factors can trigger structural changes leading to the formation of the mtPTP complex. Translocator protein (TSPO), hexokinase (HK), creatine kinase $(\mathrm{CK})$, and cyclophilin D (CypD) are the other components of mtPTP. Outer membrane (OM), inner membrane (IM).

Furthermore, it has been shown that nuclear protein TDP-43 (hyper-phosphorylated and ubiquitinated TDP-43 deposits act as inclusion bodies in the brain and spinal cord of SALS patients) also interacts with mitochondrial proteins critical for mitochondrial dynamics and mitophagy, including voltage-gated anion channel 1 (VDAC1) and prohibitin 2 (PHB2), a crucial mitophagy receptor [86]. Moreover, genetic studies (i.e., gene mutations affecting DCTN1, OPTN, TBK1, VCP, and C9ORF72) have implicated deficits in autophagy and/or mitophagy in the onset of the disease [87]. Thus, it is plausible that altered selective sequestration and subsequent degradation of the dysfunctional mitochondrion, before it causes activation of cell death, may contribute to the irreversible death of MNs. In this regard, it has been reported that ALS-FTD-linked mutations of SQSTM1/p62 disrupt selective autophagy and NRF2-dependent anti-OS mechanisms [88]. Which further suggests links between autophagy/mitophagy and OS in the pathophysiology of ALS. 
The 'glutamate hypothesis', that implicates glutamate-induced cytotoxicity, remains a primary theory of the mechanism leading to MN death. Glutamate is synthesized from glutamine by the enzyme glutaminase. This can occur in the presynaptic neuron or in neighboring glial cells. The cytosolic concentration of glutamate in glutamatergic neurons is in the mM range [89]. However, the intracellular glutamate concentration in the MNs of patients or mouse models of ALS under in vivo conditions is unknown; and it is also unknown if it is of any relevance. Glutamate is a competitive inhibitor of GSH transport into mitochondria [90], and mtGSH depletion and $\mathrm{Ca}^{2+}$ load could initiate the cascade of events causing $\mathrm{MN}$ death, including mitochondrial dysfunction, oxidative/nitrosative stress-associated damage, formation of $\mathrm{Ca}^{2+}$-rich precipitates, and the release of proapoptotic signaling molecules to the cytosol (Figure 3). Preliminary experiments performed in our lab show that MNs isolated from FUS R521C transgenic mice (which develop robust neuronal loss in the spinal cord, denervation of neuromuscular junctions, and muscle atrophy) [91] show mtGSH depletion and higher cytosolic glutamate levels as compared to normal wild-type C57BL/6 mice (Table 1) (Estrela et al., unpublished results). This potential mechanism and the underlying metabolic adaptations, and whether apoptosis is the preferent type of MN death in ALS, are under investigation in our laboratories. Figure 3 schematically outlines the main metabolite flows in the $\mathrm{MN}$ microenvironment.

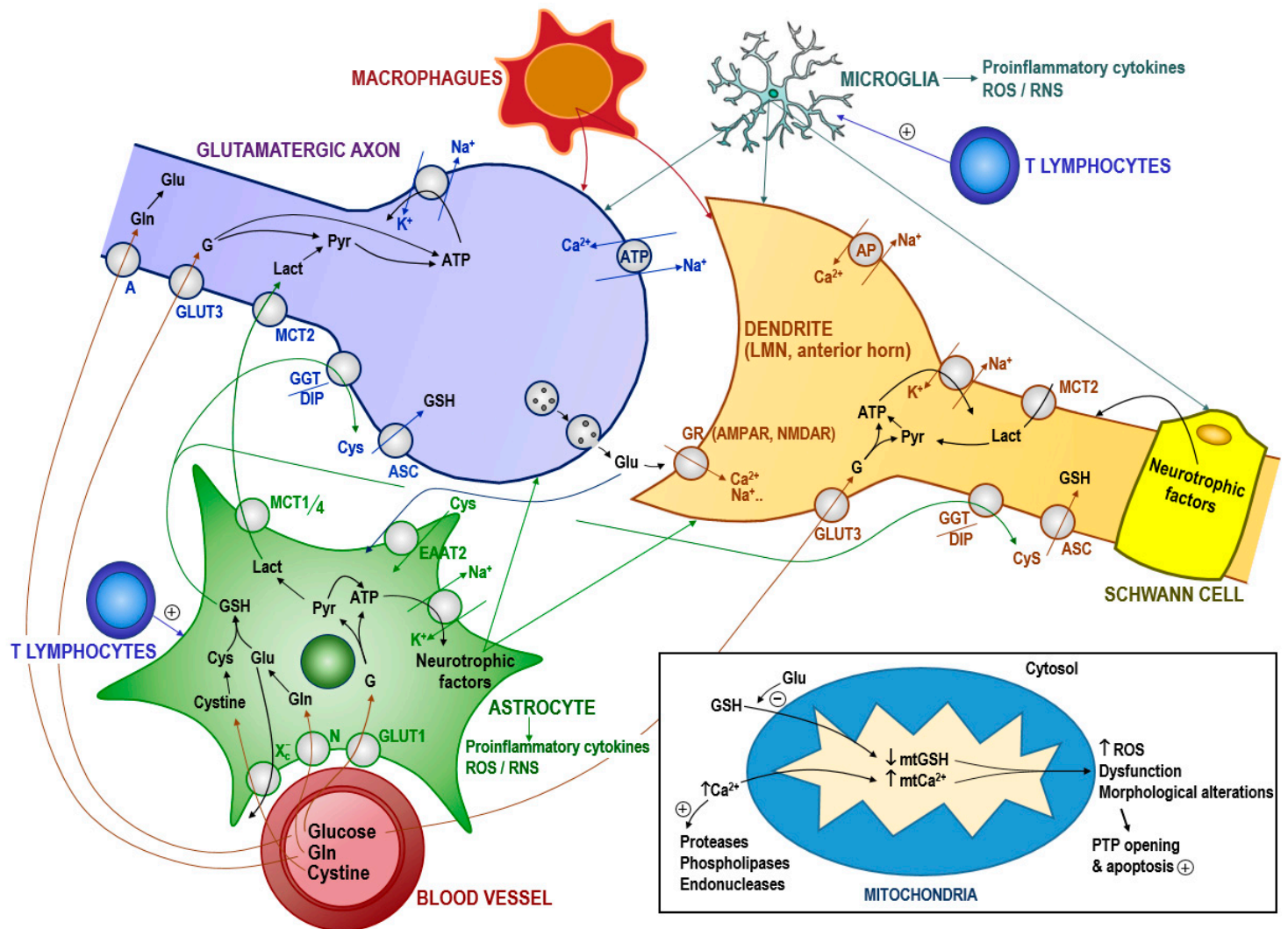

Figure 3. Fluxes of metabolites in the microenvironment of the motor neuron and the activation of mitochondria-dependent apoptosis. We can hypothesize that RNA-protein associations could theoretically be the starting point of protein misfolding leading to insoluble structures (e.g., of TDP-43) which could eventually associate to (and recruit) other native proteins. This progressive mechanism, which resembles the typical prion replication, may lead to the formation of abnormal protein complexes spreading (in the case of ALS) throughout the MN network. Interestingly some recent findings suggest that extracellular vesicles may facilitate the spread of toxic proteins and might play a role in the prion-like propagation of ALS disease [92]. Nevertheless, a mechanism mediated by a (food related?) neurotoxin cannot be ruled out. Abnormal protein- or neurotoxin-induced alteration of the interaction between glutamate and its receptor could cause glutamate accumulation in the synaptic cleft (and also 
within the presynaptic glutamatergic neuron?). This accumulation could be exacerbated by defects in astrocyte glutamate uptake due to loss of the EAAT2 transporter occurring in both SALS and FALS cases $[93,94]$. In fact, glutamate induces far greater ROS generation in cultured MNs than in other spinal neurons. Hypothetically, in the MNs a glutamate-induced inhibition of GSH uptake by mitochondria coupled with proinflammatory cytokines, such as TNF $\alpha$, could promote an increase in ROS, thereby leading to mitochondrial dysfunction and activation of cell death in a mechanism similar to that described in tumor cells [90]. Activated microglia and astrocytes express and release high levels of $\mathrm{TNF} \alpha$ [95]; these events would then activate a (more intense) local inflammatory response involving $\mathrm{T}$ lymphocytes, activated microglia and macrophages. Inflammation-associated alteration of the ionic equilibrium would favor $\mathrm{Ca}^{2+}$ influx, which would further promote mitochondrial dysfunction. Glutamate accumulation in the extracellular space would also affect cysteine uptake and, thereby, GSH synthesis in astrocytes and its export to neurons [96]. Intracellular GSH depletion facilitates the release of $\mathrm{Ca}^{2+}$ from intracellular deposits [97]. ROS (and associated RNS) could also damage different transport mechanisms such as glucose transporters. ROS/RNS-induced protein damage would also favor the formation of protein aggregates and cause impaired axonal transport. Any exogenous pro-oxidative stress factor (e.g., radiations, metal toxicity, intense physical activity, or low intake of dietary antioxidants) could aggravate the progression of the disease. Moreover, as the disease progresses, nutritional deficiency, cachexia, psychological stress, and impending respiratory failure may further increase oxidative stress leading inexorably to MN death. GR, glutamate receptors; AMPAR, $\alpha$-amino-3-hydroxy-5-methyl-4-isoxazolepropionic acid receptor; NMDAR, N-methyl-D-aspartate receptor; ROS/RNS, reactive oxygen and nitrogen species; GLUT1, glucose transporter 1; GLUT3, glucose transporter 3; $\mathrm{MCT}$, lactate transporter; EATT, excitatory amino acid transporter; N and A, Gln transporters; $\mathrm{Xc}^{-}$, cysteine/glutamate antiporter; ASC, transport system for neutral amino acids; $\mathrm{AP}$, $\mathrm{Ca}_{2}{ }^{+} / \mathrm{Na}^{+}$antiporter; GGT/DIP, $\gamma$-glutamyl transpeptidase and dipeptidases; $\mathrm{mt}$, mitochondrial. PTP, permeability transition pore complex; G, glucose; Pyr, pyruvate; Lact, lactate; GSH, glutathione; Cys, cysteine; Gln, glutamine; Glu, glutamate.

Table 1. ROS generation and levels of glutamate, GSH, GSSG and $\mathrm{Ca}^{2+}$ in motor neurons isolated from wild-type (WT) and FUS R521C mice.

\begin{tabular}{|c|c|c|c|c|c|c|}
\hline & \multicolumn{6}{|c|}{ Motor Neurons } \\
\hline & \multicolumn{3}{|c|}{ WT } & \multicolumn{3}{|c|}{ FUS R521C } \\
\hline & cyt & mt & Total & cyt & $\mathrm{mt}$ & Total \\
\hline $\mathbf{H}_{2} \mathbf{O}_{2}\left(\mathrm{nmol} / 10^{6}\right.$ cells $\left.\cdot \min \right)$ & & & $0.42 \pm 0.17$ & & & $1.06 \pm 0.33^{* *}$ \\
\hline $\mathbf{O}_{2}{ }^{\bullet-}(\Delta$ FL1, a.u. $)$ & & & $2.11 \pm 0.66$ & & & $4.33 \pm 1.20$ * \\
\hline Glutamate (nmol/106 cells) & $28.5 \pm 4.3$ & $5.6 \pm 1.4$ & & $41.7 \pm 5.9^{* *}$ & $7.2 \pm 1.8$ & \\
\hline GSH $\left(\mathrm{nmol} / 10^{6}\right.$ cells $)$ & $21.2 \pm 2.9$ & $4.3 \pm 1.2$ & & $15.0 \pm 2.4^{* *}$ & $2.1 \pm 0.5^{* *}$ & \\
\hline GSSG (nmol/106 cells) & $0.5 \pm 0.2$ & $0.2 \pm 0.05$ & & $1.0 \pm 0.3 *$ & $0.4 \pm 0.1^{* *}$ & \\
\hline $\mathrm{Ca}^{2+}$ (nmol/mg protein) & $1087 \pm 184$ & $512 \pm 96$ & & $1740 \pm 260^{* *}$ & $826 \pm 160 *$ & \\
\hline
\end{tabular}

High yield extraction and culture of pure spinal motor neurons (MNs) were performed as previously described [98]. Wild-type C57BL/6 and transgenic FUS R521C (expressing mutant FUS protein) mice were obtained from Jackson Labs. FUS R521C mice show, at postnatal day 60 , about $50 \%$ loss of anterior horn neurons (remaining motor neurons show reduced dendritic complexity and synaptic density). $\mathrm{MN}$ isolation and measurements were performed at postnatal day 100. Cytosolic (cyt) and mitochondrial (mt) compartments were rapidly separated using digitonin and centrifugation through a layer of silicon oil, as previously described for other cell types [99]. Measurement of $\mathrm{H}_{2} \mathrm{O}_{2}$ based on the $\mathrm{H}_{2} \mathrm{O}_{2}$ /horseradish peroxidase-dependent oxidation of homovanillic acid (3-methoxy-4-hydroxyphenylacetic acid) to a highly fluorescent dimer (2,2-dihydroxydiphenyl-5,5-diacetic acid) and flow cytometric determination of $\mathrm{O}_{2}{ }^{-}$generation were performed as previously described (a.u., arbitrary units) [100]. Glutamate was measured fluorometrically by a standard enzymic method [101]. Glutathione (GSH) and glutathione disulfide (GSSG) levels were determined by liquid chromatography-mass spectrometry as previously described [102]. Free $\mathrm{Ca}^{2+}$ levels were measured using the $\mathrm{Ca}^{2+}$ indicator Fura-2 AM and following the methodology described by Abcam (Cambridge, UK). Results are expressed as means \pm SD for 6-7 different experiments. ${ }^{*} p<0.05$, ${ }^{* *} p<$ 0.01 (Student's $t$-test) comparing MNs from FUS R521C versus their equivalent wild-type. 


\section{Implications in the Therapy of ALS}

Riluzole (shown to compensate for harmful extracellular glutamate levels), currently prescribed to most ALS patients, has been found to improve survival by 2-3 months [103]. In addition to its role in accelerating glutamate clearance from the synapse, riluzole may also prevent glutamate release from presynaptic terminals [104] and therefore could favor pathophysiology (Figure 3). Edaravone (an antioxidant) was approved for the treatment of ALS in the US in 2017 based on the results from a randomized placebo-controlled clinical trial in subjects with early-stage ALS in Japan (NCT01492686, www.clinicaltrials.gov). In this trial edaravone significantly slowed the 24-week decline in functionality, measured via the revised ALS functional rating scale (ALSFRS-R), in the edaravone-treated group relative to placebo ( -5.01 compared to -7.50 , respectively). However, edaravone has failed to demonstrate efficacy in two trials in patients with all stages of ALS, and may not be a viable treatment option for the wider patient population $[105,106]$.

Other therapeutic approaches under consideration have been recently reviewed [107] and include: (a) masitinib [108] which demonstrated a $27 \%$ reduction in functional decline when administered along with riluzole in a 48-week placebo-controlled phase 3 trial. Masitinib, a tyrosine kinase inhibitor, is predicted to work by reducing microglia-based inflammation of MNs in the brain and spinal cord (NCT02588677, www.clinicaltrials.gov); (b) AMX0035, a combination of sodium phenylbutyrate and tauroursodeoxycholic acid, aimed to reduce nerve cell death by limiting cell death and neuroinflammation; (c) antisense therapy; (d) gene therapy; or (e) stem-cell therapy using mesenchymal stromal cells isolated from e.g., adipose tissue. Mesenchymal stromal cells secrete small proteins (e.g., neurotrophic factors) that support the survival of motor neurons and also support the immune system, which may be relevant given a role for the immune system and its associated inflammation in ALS. At present all other clinical procedures used in ALS patients are essentially palliative: breathing support, physical therapy, and end of life care.

Based on available evidences and the pathophysiology mechanisms described above, we might suggest other options to be also explored, i.e., therapeutic agents to control the intracellular glutamate cytotoxicity (e.g., necrostatin-1) [109,110]; anti-inflammatory drugs [111,112]; specific cannabinoid receptors such as CB2 (to improve neuroprotection) [113]; metal chelators, e.g., the iron chelator deferiprone (to limit metal-induced toxicity leading to OS) [114]; neurotrophins (to promote neuroplasticity) [115]; cyclic nucleotide phosphodiesterase (PDE) inhibitors to prevent glial cell activation (e.g., ibudilast) [116]; antiretrovirals (e.g., TRIUMEQ ${ }^{\circledR}$, a combination of abacavir sulfate, dolutegravir sodium, and lamivudine) used as an anti-HIV therapy, and based on the fact that ALS patients present serum concentrations of reverse transcriptase comparable to HIV-infected patients [117]; antiepileptic drugs (e.g., retigabine, which acts by binding to the voltage-gated $\mathrm{K}^{+}$channels and increasing the M-current, thus leading to membrane hyperpolarization and decreasing excitability) [118]; or the antiestrogen tamoxifen (some neurological improvements have been observed in ALS patients with breast cancer and treated with tamoxifen-an effect possibly related to the inhibition of protein kinase C, which is overexpressed in the spinal cord of ALS patients) (see e.g., NCT00214110 under www.clinicaltrials.gov).

\section{Concluding Remarks}

In light of recent evidences highlighting the therapeutic potential of sirtuin activation and $\mathrm{NAD}^{+}$ repletion, a sequential cascade of events in the pathophysiology of ALS begins to be visualized.

Neuroinflammation, involving reactive astrocytes and microglia, and peripheral immune cells, promotes OS in the MN microenvironment. In this scenario many of the suggested causes/factors of SALS could be secondary, with the plausible exception of an infectious agent and/or an autoimmune mechanism. Neurodegeneration and the death of the MN would be the consequence of these initial phenomena. Experimental evidences suggest that damage to mitochondria could be a key mechanism involved in the final activation of neuronal death. 
New therapeutic combinations could hopefully offer options to control the disease and extend the life expectancy of patients. In order to fulfil this aim, targeting patients early in their disease course may be critical. Finally, given the heterogeneity of disease progression, as well as key pathogenic differences according to disease stage, precision approaches combining genomics, biomarkers, imaging markers, and targeted/combined therapeutics may help to improve the clinical outcome.

Author Contributions: Conceptualization, E.O. and J.M.E.; methodology, R.L.-B. and A.J.-J.; software, R.S.; validation, E.O., R.S. and J.M.E.; formal analysis, R.S. and S.L.V.; investigation, R.L.-B., A.J.-J. and S.L.V.; resources, J.M.E.; data curation, R.S.; writing—original draft preparation, E.O. and J.M.E.; writing-review and editing, J.M.E.; visualization, E.O.; supervision, J.M.E.; project administration, J.M.E.; funding acquisition, E.O. and J.M.E. All authors have read and agreed to the published version of the manuscript.

Funding: Research was supported by grants from the University of Valencia (Spain) and Elysium Health Inc. (New York, NY, USA).

Conflicts of Interest: The authors declare no conflict of interest.

\section{References}

1. Couratier, P.; Corcia, P.; Lautrette, G.; Nicol, M.; Preux, P.-M.; Marin, B. Epidemiology of amyotrophic lateral sclerosis: A review of literature. Rev. Neurol. 2016, 172, 37-45. [CrossRef] [PubMed]

2. Traxinger, K.; Kelly, C.; Johnson, B.A.; Lyles, R.H.; Glass, J.D. Prognosis and epidemiology of amyotrophic lateral sclerosis: Analysis of a clinic population, 1997-2011. Neurol. Clin. Pract. 2013, 3, 313-320. [CrossRef] [PubMed]

3. Martin, S.; Al Khleifat, A.; Al-Chalabi, A. What causes amyotrophic lateral sclerosis? F1000Research 2017, 6, 371. [CrossRef] [PubMed]

4. Al-Chalabi, A.; van den Berg, L.H.; Veldink, J. Gene discovery in amyotrophic lateral sclerosis: Implications for clinical management. Nat. Rev. Neurol. 2017, 13, 96-104. [CrossRef]

5. Taylor, J.P.; Brown, R.H.; Cleveland, D.W. Decoding ALS: From genes to mechanism. Nature 2016, 539, 197-206. [CrossRef]

6. Morozova, N.; Weisskopf, M.G.; McCullough, M.L.; Munger, K.L.; Calle, E.E.; Thun, M.J.; Ascherio, A. Diet and amyotrophic lateral sclerosis. Epidemiology 2008, 19, 324-337. [CrossRef]

7. Murdock, B.J.; Bender, D.E.; Segal, B.M.; Feldman, E.L. The dual roles of immunity in ALS: Injury overrides protection. Neurobiol. Dis. 2015, 77, 1-12. [CrossRef]

8. Gardner, R.C.; Yaffe, K. Epidemiology of mild traumatic brain injury and neurodegenerative disease. Mol. Cell. Neurosci. 2015, 66, 75-80. [CrossRef]

9. Lacorte, E.; Ferrigno, L.; Leoncini, E.; Corbo, M.; Boccia, S.; Vanacore, N. Physical activity, and physical activity related to sports, leisure and occupational activity as risk factors for ALS: A systematic review. Neurosci. Biobehav. Rev. 2016, 66, 61-79. [CrossRef]

10. Cicero, C.E.; Mostile, G.; Vasta, R.; Rapisarda, V.; Signorelli, S.S.; Ferrante, M.; Zappia, M.; Nicoletti, A. Metals and neurodegenerative diseases. A systematic review. Environ. Res. 2017, 159, 82-94. [CrossRef]

11. Gunnarsson, L.-G.; Bodin, L. Amyotrophic Lateral Sclerosis and Occupational Exposures: A Systematic Literature Review and Meta-Analyses. Int. J. Environ. Res. Public Health 2018, 15, 2371. [CrossRef] [PubMed]

12. Smith, E.F.; Shaw, P.J.; De Vos, K.J. The role of mitochondria in amyotrophic lateral sclerosis. Neurosci. Lett. 2017, 710, 132933. [CrossRef] [PubMed]

13. Takeda, T. Possible concurrence of TDP-43, tau and other proteins in amyotrophic lateral sclerosis/frontotemporal lobar degeneration. Neuropathology 2018, 38, 72-81. [CrossRef] [PubMed]

14. Castanedo-Vazquez, D.; Bosque-Varela, P.; Sainz-Pelayo, A.; Riancho, J. Infectious agents and amyotrophic lateral sclerosis: Another piece of the puzzle of motor neuron degeneration. J. Neurol. 2019, 266, 27-36. [CrossRef] [PubMed]

15. Hamidou, B.; Marin, B.; Lautrette, G.; Nicol, M.; Camu, W.; Corcia, P.; Arnes-Bes, M.-C.; Tranchant, C.; Clavelou, P.; Hannequin, D.; et al. Exploring the diagnosis delay and ALS functional impairment at diagnosis as relevant criteria for clinical trial enrolment. Amyotroph Lateral Scler. Front. Degener 2017, 18, 519-527. [CrossRef]

16. Gordon, P.H. Amyotrophic Lateral Sclerosis: An update for 2013 Clinical Features, Pathophysiology, Management and Therapeutic Trials. Aging Dis. 2013, 4, 295-310. [CrossRef] 
17. Liu, J.; Wang, F. Role of Neuroinflammation in Amyotrophic Lateral Sclerosis: Cellular Mechanisms and Therapeutic Implications. Front. Immunol. 2017, 8, 1005. [CrossRef]

18. Filiano, A.J.; Gadani, S.P.; Kipnis, J. Interactions of innate and adaptive immunity in brain development and function. Brain Res. 2015, 1617, 18-27. [CrossRef]

19. Ransohoff, R.M. How neuroinflammation contributes to neurodegeneration. Science 2016, 353, 777-783. [CrossRef]

20. Vargas, M.R.; Johnson, J.A. Astrogliosis in amyotrophic lateral sclerosis: Role and therapeutic potential of astrocytes. Neurotherapeutics 2010, 7, 471-481. [CrossRef]

21. Radford, R.A.; Morsch, M.; Rayner, S.L.; Cole, N.J.; Pountney, D.L.; Chung, R.S. The established and emerging roles of astrocytes and microglia in amyotrophic lateral sclerosis and frontotemporal dementia. Front. Cell. Neurosci. 2015, 9, 414. [CrossRef] [PubMed]

22. Haidet-Phillips, A.M.; Hester, M.E.; Miranda, C.J.; Meyer, K.; Braun, L.; Frakes, A.; Song, S.; Likhite, S.; Murtha, M.J.; Foust, K.D.; et al. Astrocytes from familial and sporadic ALS patients are toxic to motor neurons. Nat. Biotechnol. 2011, 29, 824-828. [CrossRef] [PubMed]

23. Trias, E.; King, P.H.; Si, Y.; Kwon, Y.; Varela, V.; Ibarburu, S.; Kovacs, M.; Moura, I.C.; Beckman, J.S.; Hermine, O.; et al. Mast cells and neutrophils mediate peripheral motor pathway degeneration in ALS. JCI Insight 2018, 3, e123249. [CrossRef] [PubMed]

24. Lasiene, J.; Yamanaka, K. Glial cells in amyotrophic lateral sclerosis. Neurol. Res. Int. 2011, 2011, 718987. [CrossRef]

25. Liddelow, S.A.; Guttenplan, K.A.; Clarke, L.E.; Bennett, F.C.; Bohlen, C.J.; Schirmer, L.; Bennett, M.L.; Münch, A.E.; Chung, W.-S.; Peterson, T.C.; et al. Neurotoxic reactive astrocytes are induced by activated microglia. Nature 2017, 541, 481-487. [CrossRef]

26. Chen, X.; Hu, Y.; Cao, Z.; Liu, Q.; Cheng, Y. Cerebrospinal Fluid Inflammatory Cytokine Aberrations in Alzheimer's Disease, Parkinson's Disease and Amyotrophic Lateral Sclerosis: A Systematic Review and Meta-Analysis. Front. Immunol. 2018, 9, 2122. [CrossRef]

27. Chen, Y.; Xia, K.; Chen, L.; Fan, D. Increased Interleukin-6 Levels in the Astrocyte-Derived Exosomes of Sporadic Amyotrophic Lateral Sclerosis Patients. Front. Neurosci. 2019, 13, 574. [CrossRef]

28. Oeckl, P.; Weydt, P.; Steinacker, P.; Anderl-Straub, S.; Nordin, F.; Volk, A.E.; Diehl-Schmid, J.; Andersen, P.M.; Kornhuber, J.; Danek, A.; et al. Different neuroinflammatory profile in amyotrophic lateral sclerosis and frontotemporal dementia is linked to the clinical phase. J. Neurol. Neurosurg. Psychiatry 2019, 90, 4-10. [CrossRef] [PubMed]

29. Hooten, K.G.; Beers, D.R.; Zhao, W.; Appel, S.H. Protective and Toxic Neuroinflammation in Amyotrophic Lateral Sclerosis. Neurotherapeutics 2015, 12, 364-375. [CrossRef] [PubMed]

30. Graves, M.C.; Fiala, M.; Dinglasan, L.A.V.; Liu, N.Q.; Sayre, J.; Chiappelli, F.; van Kooten, C.; Vinters, H.V. Inflammation in amyotrophic lateral sclerosis spinal cord and brain is mediated by activated macrophages, mast cells and T cells. Amyotroph. Lateral Scler. Other Mot. Neuron Disord. 2004, 5, 213-219. [CrossRef] [PubMed]

31. Bettelli, E.; Carrier, Y.; Gao, W.; Korn, T.; Strom, T.B.; Oukka, M.; Weiner, H.L.; Kuchroo, V.K. Reciprocal developmental pathways for the generation of pathogenic effector TH17 and regulatory T cells. Nature 2006, 441, 235-238. [CrossRef]

32. Chiu, I.M.; Chen, A.; Zheng, Y.; Kosaras, B.; Tsiftsoglou, S.A.; Vartanian, T.K.; Brown, R.H.; Carroll, M.C. T lymphocytes potentiate endogenous neuroprotective inflammation in a mouse model of ALS. Proc. Natl. Acad. Sci. USA 2008, 105, 17913-17918. [CrossRef] [PubMed]

33. Zhao, W.; Beers, D.R.; Liao, B.; Henkel, J.S.; Appel, S.H. Regulatory T lymphocytes from ALS mice suppress microglia and effector T lymphocytes through different cytokine-mediated mechanisms. Neurobiol. Dis. 2012, 48, 418-428. [CrossRef] [PubMed]

34. Henkel, J.S.; Beers, D.R.; Wen, S.; Rivera, A.L.; Toennis, K.M.; Appel, J.E.; Zhao, W.; Moore, D.H.; Powell, S.Z.; Appel, S.H. Regulatory T-lymphocytes mediate amyotrophic lateral sclerosis progression and survival. EMBO Mol. Med. 2013, 5, 64-79. [CrossRef] [PubMed]

35. Sies, H. Oxidative stress: A concept in redox biology and medicine. Redox Biol. 2015, 4, 180-183. [CrossRef] [PubMed]

36. D'Ambrosi, N.; Cozzolino, M.; Carrì, M.T. Neuroinflammation in Amyotrophic Lateral Sclerosis: Role of Redox (dys) Regulation. Antioxid. Redox Signal. 2018, 29, 15-36. [CrossRef] 
37. Pollari, E.; Goldsteins, G.; Bart, G.; Koistinaho, J.; Giniatullin, R. The role of oxidative stress in degeneration of the neuromuscular junction in amyotrophic lateral sclerosis. Front. Cell. Neurosci. 2014, 8, 131. [CrossRef]

38. Weiduschat, N.; Mao, X.; Hupf, J.; Armstrong, N.; Kang, G.; Lange, D.J.; Mitsumoto, H.; Shungu, D.C. Motor cortex glutathione deficit in ALS measured in vivo with the J-editing technique. Neurosci. Lett. 2014, 570, 102-107. [CrossRef]

39. Cohen, T.J.; Hwang, A.W.; Unger, T.; Trojanowski, J.Q.; Lee, V.M.Y. Redox signalling directly regulates TDP-43 via cysteine oxidation and disulphide cross-linking. EMBO J. 2012, 31, 1241-1252. [CrossRef]

40. Duan, W.; Li, X.; Shi, J.; Guo, Y.; Li, Z.; Li, C. Mutant TAR DNA-binding protein-43 induces oxidative injury in motor neuron-like cell. Neuroscience 2010, 169, 1621-1629. [CrossRef]

41. Shodai, A.; Morimura, T.; Ido, A.; Uchida, T.; Ayaki, T.; Takahashi, R.; Kitazawa, S.; Suzuki, S.; Shirouzu, M.; Kigawa, T.; et al. Aberrant assembly of RNA recognition motif 1 links to pathogenic conversion of TAR DNA-binding protein of 43 kDa (TDP-43). J. Biol. Chem. 2013, 288, 14886-14905. [CrossRef]

42. Petri, S.; Körner, S.; Kiaei, M. Nrf2/ARE Signaling Pathway: Key Mediator in Oxidative Stress and Potential Therapeutic Target in ALS. Neurol. Res. Int. 2012, 2012, 878030. [CrossRef] [PubMed]

43. Vargas, M.R.; Pehar, M.; Cassina, P.; Beckman, J.S.; Barbeito, L. Increased glutathione biosynthesis by Nrf2 activation in astrocytes prevents p75NTR-dependent motor neuron apoptosis. J. Neurochem. 2006, 97, 687-696. [CrossRef] [PubMed]

44. Neymotin, A.; Calingasan, N.Y.; Wille, E.; Naseri, N.; Petri, S.; Damiano, M.; Liby, K.T.; Risingsong, R.; Sporn, M.; Beal, M.F.; et al. Neuroprotective effect of Nrf2/ARE activators, CDDO ethylamide and CDDO trifluoroethylamide, in a mouse model of amyotrophic lateral sclerosis. Free Radic. Biol. Med. 2011, 51, 88-96. [CrossRef] [PubMed]

45. Wiedemann, F.R.; Manfredi, G.; Mawrin, C.; Beal, M.F.; Schon, E.A. Mitochondrial DNA and respiratory chain function in spinal cords of ALS patients. J. Neurochem. 2002, 80, 616-625. [CrossRef]

46. Ghiasi, P.; Hosseinkhani, S.; Noori, A.; Nafissi, S.; Khajeh, K. Mitochondrial complex I deficiency and ATP/ADP ratio in lymphocytes of amyotrophic lateral sclerosis patients. Neurol. Res. 2012, 34, 297-303. [CrossRef]

47. Israelson, A.; Arbel, N.; Da Cruz, S.; Ilieva, H.; Yamanaka, K.; Shoshan-Barmatz, V.; Cleveland, D.W. Misfolded mutant SOD1 directly inhibits VDAC1 conductance in a mouse model of inherited ALS. Neuron 2010, 67, 575-587. [CrossRef]

48. Imai, S.; Guarente, L. NAD+ and sirtuins in aging and disease. Trends Cell Biol. 2014, 24, 464-471. [CrossRef]

49. Bause, A.S.; Haigis, M.C. SIRT3 regulation of mitochondrial oxidative stress. Exp. Gerontol. 2013, 48, 634-639. [CrossRef]

50. Han, S.; Choi, J.-R.; Soon Shin, K.; Kang, S.J. Resveratrol upregulated heat shock proteins and extended the survival of G93A-SOD1 mice. Brain Res. 2012, 1483, 112-117. [CrossRef]

51. Herskovits, A.Z.; Hunter, T.A.; Maxwell, N.; Pereira, K.; Whittaker, C.A.; Valdez, G.; Guarente, L.P. SIRT1 deacetylase in aging-induced neuromuscular degeneration and amyotrophic lateral sclerosis. Aging Cell 2018, 17, e12839. [CrossRef] [PubMed]

52. Tang, B.L. Sirt1 and the Mitochondria. Mol. Cells 2016, 39, 87-95. [PubMed]

53. Thau, N.; Knippenberg, S.; Körner, S.; Rath, K.J.; Dengler, R.; Petri, S. Decreased mRNA expression of PGC- $1 \alpha$ and PGC- $1 \alpha$-regulated factors in the SOD1G93A ALS mouse model and in human sporadic ALS. J. Neuropathol. Exp. Neurol. 2012, 71, 1064-1074. [CrossRef]

54. Song, W.; Song, Y.; Kincaid, B.; Bossy, B.; Bossy-Wetzel, E. Mutant SOD1G93A triggers mitochondrial fragmentation in spinal cord motor neurons: Neuroprotection by SIRT3 and PGC- $1 \alpha$. Neurobiol. Dis. 2013, 51, 72-81. [CrossRef] [PubMed]

55. Salvatori, I.; Valle, C.; Ferri, A.; Carrì, M.T. SIRT3 and mitochondrial metabolism in neurodegenerative diseases. Neurochem. Int. 2017, 109, 184-192. [CrossRef] [PubMed]

56. Pasinetti, G.M.; Bilski, A.E.; Zhao, W. Sirtuins as therapeutic targets of ALS. Cell Res. 2013, 23, $1073-1074$. [CrossRef]

57. Harlan, B.A.; Pehar, M.; Sharma, D.R.; Beeson, G.; Beeson, C.C.; Vargas, M.R. Enhancing NAD+ Salvage Pathway Reverts the Toxicity of Primary Astrocytes Expressing Amyotrophic Lateral Sclerosis-linked Mutant Superoxide Dismutase 1 (SOD1). J. Biol. Chem. 2016, 291, 10836-10846. [CrossRef] 
58. De la Rubia, J.E.; Drehmer, E.; Platero, J.L.; Benlloch, M.; Caplliure-Llopis, J.; Villaron-Casales, C.; de Bernardo, N.; AlarcÓn, J.; Fuente, C.; Carrera, S.; et al. Efficacy and tolerability of EH301 for amyotrophic lateral sclerosis: A randomized, double-blind, placebo-controlled human pilot study. Amyotroph Lateral Scler. Front. Degener. 2019, 20, 115-122. [CrossRef]

59. Trammell, S.A.J.; Schmidt, M.S.; Weidemann, B.J.; Redpath, P.; Jaksch, F.; Dellinger, R.W.; Li, Z.; Abel, E.D.; Migaud, M.E.; Brenner, C. Nicotinamide riboside is uniquely and orally bioavailable in mice and humans. Nat. Commun. 2016, 7, 12948. [CrossRef]

60. Zhou, M.; Ottenberg, G.; Sferrazza, G.F.; Hubbs, C.; Fallahi, M.; Rumbaugh, G.; Brantley, A.F.; Lasmézas, C.I. Neuronal death induced by misfolded prion protein is due to NAD+ depletion and can be relieved in vitro and in vivo by NAD+ replenishment. Brain 2015, 138, 992-1008. [CrossRef]

61. Wang, P.; Xu, T.-Y.; Guan, Y.-F.; Tian, W.-W.; Viollet, B.; Rui, Y.-C.; Zhai, Q.-W.; Su, D.-F.; Miao, C.-Y. Nicotinamide phosphoribosyltransferase protects against ischemic stroke through SIRT1-dependent adenosine monophosphate-activated kinase pathway. Ann. Neurol. 2011, 69, 360-374. [CrossRef] [PubMed]

62. Gerdts, J.; Brace, E.J.; Sasaki, Y.; DiAntonio, A.; Milbrandt, J. SARM1 activation triggers axon degeneration locally via NAD ${ }^{+}$destruction. Science 2015, 348, 453-457. [CrossRef] [PubMed]

63. Murphy, M.P. How mitochondria produce reactive oxygen species. Biochem. J. 2009, 417, 1-13. [CrossRef] [PubMed]

64. Song, S.B.; Jang, S.-Y.; Kang, H.T.; Wei, B.; Jeoun, U.-W.; Yoon, G.S.; Hwang, E.S. Modulation of Mitochondrial Membrane Potential and ROS Generation by Nicotinamide in a Manner Independent of SIRT1 and Mitophagy. Mol. Cells 2017, 40, 503-514.

65. Estrela, J.M.; Ortega, A.; Mena, S.; Rodriguez, M.L.; Asensi, M. Pterostilbene: Biomedical applications. Crit Rev. Clin. Lab. Sci. 2013, 50, 65-78. [CrossRef] [PubMed]

66. Mancuso, R.; del Valle, J.; Modol, L.; Martinez, A.; Granado-Serrano, A.B.; Ramirez-Núñez, O.; Pallás, M.; Portero-Otin, M.; Osta, R.; Navarro, X. Resveratrol improves motoneuron function and extends survival in SOD1(G93A) ALS mice. Neurotherapeutics 2014, 11, 419-432.

67. Song, L.; Chen, L.; Zhang, X.; Li, J.; Le, W. Resveratrol ameliorates motor neuron degeneration and improves survival in SOD1G93A mouse model of amyotrophic lateral sclerosis. Biomed Res. Int. 2014, 2014. [CrossRef]

68. Wang, B.; Liu, H.; Yue, L.; Li, X.; Zhao, L.; Yang, X.; Wang, X.; Yang, Y.; Qu, Y. Neuroprotective effects of pterostilbene against oxidative stress injury: Involvement of nuclear factor erythroid 2-related factor 2 pathway. Brain Res. 2016, 1643, 70-79. [CrossRef]

69. Liu, H.; Zhao, L.; Yue, L.; Wang, B.; Li, X.; Guo, H.; Ma, Y.; Yao, C.; Gao, L.; Deng, J.; et al. Pterostilbene Attenuates Early Brain Injury Following Subarachnoid Hemorrhage via Inhibition of the NLRP3 Inflammasome and Nox2-Related Oxidative Stress. Mol. Neurobiol. 2017, 54, 5928-5940. [CrossRef]

70. Deora, V.; Lee, J.D.; Albornoz, E.A.; McAlary, L.; Jagaraj, C.J.; Robertson, A.A.B.; Atkin, J.D.; Cooper, M.A.; Schroder, K.; Yerbury, J.J.; et al. The microglial NLRP3 inflammasome is activated by amyotrophic lateral sclerosis proteins. Glia 2020, 68, 407-421. [CrossRef]

71. Circu, M.L.; Aw, T.Y. Glutathione and apoptosis. Free Radic. Res. 2008, 42, 689-706. [CrossRef] [PubMed]

72. Mytilineou, C.; Kokotos Leonardi, E.T.; Kramer, B.C.; Jamindar, T.; Olanow, C.W. Glial cells mediate toxicity in glutathione-depleted mesencephalic cultures. J. Neurochem. 1999, 73, 112-119. [CrossRef]

73. Xue, F.; Huang, J.-W.; Ding, P.-Y.; Zang, H.-G.; Kou, Z.-J.; Li, T.; Fan, J.; Peng, Z.-W.; Yan, W.-J. Nrf2/antioxidant defense pathway is involved in the neuroprotective effects of Sirt1 against focal cerebral ischemia in rats after hyperbaric oxygen preconditioning. Behav. Brain Res. 2016, 309, 1-8. [CrossRef]

74. Mimoto, T.; Miyazaki, K.; Morimoto, N.; Kurata, T.; Satoh, K.; Ikeda, Y.; Abe, K. Impaired antioxydative Keap1/Nrf2 system and the downstream stress protein responses in the motor neuron of ALS model mice. Brain Res. 2012, 1446, 109-118. [CrossRef]

75. Cheng, Y.; Di, S.; Fan, C.; Cai, L.; Gao, C.; Jiang, P.; Hu, W.; Ma, Z.; Jiang, S.; Dong, Y.; et al. SIRT1 activation by pterostilbene attenuates the skeletal muscle oxidative stress injury and mitochondrial dysfunction induced by ischemia reperfusion injury. Apoptosis 2016, 21, 905-916. [CrossRef]

76. Jia, N.; Sun, Q.; Su, Q.; Chen, G. SIRT1-mediated deacetylation of PGC1 $\alpha$ attributes to the protection of curcumin against glutamate excitotoxicity in cortical neurons. Biochem. Biophys. Res. Commun. 2016, 478, 1376-1381. [CrossRef] 
77. Xu, S.; Gao, Y.; Zhang, Q.; Wei, S.; Chen, Z.; Dai, X.; Zeng, Z.; Zhao, K.-S. SIRT1/3 Activation by Resveratrol Attenuates Acute Kidney Injury in a Septic Rat Model. Oxid. Med. Cell. Longev. 2016, 2016, 7296092. [CrossRef]

78. Dai, S.-H.; Chen, T.; Wang, Y.-H.; Zhu, J.; Luo, P.; Rao, W.; Yang, Y.-F.; Fei, Z.; Jiang, X.-F. Sirt3 protects cortical neurons against oxidative stress via regulating mitochondrial $\mathrm{Ca} 2+$ and mitochondrial biogenesis. Int. J. Mol. Sci. 2014, 15, 14591-14609. [CrossRef]

79. Shulyakova, N.; Sidorova-Darmos, E.; Fong, J.; Zhang, G.; Mills, L.R.; Eubanks, J.H. Over-expression of the Sirt3 sirtuin Protects neuronally differentiated PC12 Cells from degeneration induced by oxidative stress and trophic withdrawal. Brain Res. 2014, 1587, 40-53. [CrossRef]

80. Belzacq, A.-S.; Vieira, H.L.A.; Kroemer, G.; Brenner, C. The adenine nucleotide translocator in apoptosis. Biochimie 2002, 84, 167-176. [CrossRef]

81. Martin, L.J. Mitochondrial pathobiology in ALS. J. Bioenerg. Biomembr. 2011, 43, 569-579. [CrossRef]

82. Halestrap, A.P.; Brenner, C. The adenine nucleotide translocase: A central component of the mitochondrial permeability transition pore and key player in cell death. Curr. Med. Chem. 2003, 10, 1507-1525. [CrossRef]

83. Vieira, H.L.; Belzacq, A.S.; Haouzi, D.; Bernassola, F.; Cohen, I.; Jacotot, E.; Ferri, K.F.; El Hamel, C.; Bartle, L.M.; Melino, G.; et al. The adenine nucleotide translocator: A target of nitric oxide, peroxynitrite, and 4-hydroxynonenal. Oncogene 2001, 20, 4305-4316. [CrossRef]

84. Martin, L.J.; Gertz, B.; Pan, Y.; Price, A.C.; Molkentin, J.D.; Chang, Q. The mitochondrial permeability transition pore in motor neurons: Involvement in the pathobiology of ALS mice. Exp. Neurol. 2009, 218, 333-346. [CrossRef]

85. Schuler, M.; Bossy-Wetzel, E.; Goldstein, J.C.; Fitzgerald, P.; Green, D.R. p53 induces apoptosis by caspase activation through mitochondrial cytochrome c release. J. Biol. Chem. 2000, 275, 7337-7342. [CrossRef]

86. Davis, S.A.; Itaman, S.; Khalid-Janney, C.M.; Sherard, J.A.; Dowell, J.A.; Cairns, N.J.; Gitcho, M.A. TDP-43 interacts with mitochondrial proteins critical for mitophagy and mitochondrial dynamics. Neurosci. Lett. 2018, 678, 8-15. [CrossRef]

87. Evans, C.S.; Holzbaur, E.L.F. Autophagy and mitophagy in ALS. Neurobiol. Dis. 2019, 122, 35-40. [CrossRef]

88. Deng, Z.; Lim, J.; Wang, Q.; Purtell, K.; Wu, S.; Palomo, G.M.; Tan, H.; Manfredi, G.; Zhao, Y.; Peng, J.; et al. ALS-FTLD-linked mutations of SQSTM1/p62 disrupt selective autophagy and NFE2L2/NRF2 anti-oxidative stress pathway. Autophagy 2020, 16, 917-931. [CrossRef]

89. Featherstone, D.E. Intercellular glutamate signaling in the nervous system and beyond. ACS Chem. Neurosci. 2010, 1, 4-12. [CrossRef]

90. Carretero, J.; Obrador, E.; Pellicer, J.A.; Pascual, A.; Estrela, J.M. Mitochondrial glutathione depletion by glutamine in growing tumor cells. Free Radic. Biol. Med. 2000, 29, 913-923. [CrossRef]

91. Qiu, H.; Lee, S.; Shang, Y.; Wang, W.-Y.; Au, K.F.; Kamiya, S.; Barmada, S.J.; Finkbeiner, S.; Lui, H.; Carlton, C.E.; et al. ALS-associated mutation FUS-R521C causes DNA damage and RNA splicing defects. J. Clin. Investig. 2014, 124, 981-999. [CrossRef] [PubMed]

92. Sproviero, D.; La Salvia, S.; Giannini, M.; Crippa, V.; Gagliardi, S.; Bernuzzi, S.; Diamanti, L.; Ceroni, M.; Pansarasa, O.; Poletti, A.; et al. Pathological Proteins Are Transported by Extracellular Vesicles of Sporadic Amyotrophic Lateral Sclerosis Patients. Front. Neurosci. 2018, 12, 487. [CrossRef] [PubMed]

93. Bruijn, L.I.; Becher, M.W.; Lee, M.K.; Anderson, K.L.; Jenkins, N.A.; Copeland, N.G.; Sisodia, S.S.; Rothstein, J.D.; Borchelt, D.R.; Price, D.L.; et al. ALS-linked SOD1 mutant G85R mediates damage to astrocytes and promotes rapidly progressive disease with SOD1-containing inclusions. Neuron 1997, 18, 327-338. [CrossRef]

94. Yamanaka, K.; Komine, O. The multi-dimensional roles of astrocytes in ALS. Neurosci. Res. 2018, 126, 31-38. [CrossRef] [PubMed]

95. Neniskyte, U.; Vilalta, A.; Brown, G.C. Tumour necrosis factor alpha-induced neuronal loss is mediated by microglial phagocytosis. FEBS Lett. 2014, 588, 2952-2956. [CrossRef]

96. Minich, T.; Riemer, J.; Schulz, J.B.; Wielinga, P.; Wijnholds, J.; Dringen, R. The multidrug resistance protein 1 (Mrp1), but not Mrp5, mediates export of glutathione and glutathione disulfide from brain astrocytes. J. Neurochem. 2006, 97, 373-384. [CrossRef]

97. Nicotera, P.; Bellomo, G.; Orrenius, S. Calcium-mediated mechanisms in chemically induced cell death. Annu. Rev. Pharmacol. Toxicol. 1992, 32, 449-470. [CrossRef] 
98. Beaudet, M.-J.; Yang, Q.; Cadau, S.; Blais, M.; Bellenfant, S.; Gros-Louis, F.; Berthod, F. High yield extraction of pure spinal motor neurons, astrocytes and microglia from single embryo and adult mouse spinal cord. Sci. Rep. 2015, 5, 16763. [CrossRef]

99. Obrador, E.; Navarro, J.; Mompo, J.; Asensi, M.; Pellicer, J.A.; Estrela, J.M. Glutathione and the rate of cellular proliferation determine tumour cell sensitivity to tumour necrosis factor in vivo. Biochem. J. 1997, 325 Pt 1, 183-189. [CrossRef]

100. Benlloch, M.; Mena, S.; Ferrer, P.; Obrador, E.; Asensi, M.; Pellicer, J.A.; Carretero, J.; Ortega, A.; Estrela, J.M. Bcl-2 and Mn-SOD antisense oligodeoxynucleotides and a glutamine-enriched diet facilitate elimination of highly resistant B16 melanoma cells by tumor necrosis factor-alpha and chemotherapy. J. Biol. Chem. 2006, 281, 69-79. [CrossRef]

101. Bergmeyer, H.U.; Bernt, E. UV-Assay with Pyruvate and NADH. In Methods of Enzymatic Analysis, 2nd ed.; Bergmeyer, H.U., Ed.; Academic Press: Cambridge, MA, USA, 1974; pp. 574-579.

102. Obrador, E.; Valles, S.L.; Benlloch, M.; Sirerol, J.A.; Pellicer, J.A.; Alcácer, J.; Coronado, J.A.-F.; Estrela, J.M. Glucocorticoid receptor knockdown decreases the antioxidant protection of B16 melanoma cells: An endocrine system-related mechanism that compromises metastatic cell resistance to vascular endothelium-induced tumor cytotoxicity. PLoS ONE 2014, 9, e96466. [CrossRef] [PubMed]

103. Miller, R.G.; Mitchell, J.D.; Moore, D.H. Riluzole for amyotrophic lateral sclerosis (ALS)/motor neuron disease (MND). Cochrane Database Syst. Rev. 2012, CD001447. [CrossRef] [PubMed]

104. Wang, S.-J.; Wang, K.-Y.; Wang, W.-C. Mechanisms underlying the riluzole inhibition of glutamate release from rat cerebral cortex nerve terminals (synaptosomes). Neuroscience 2004, 125, 191-201. [CrossRef] [PubMed]

105. Petrov, D.; Mansfield, C.; Moussy, A.; Hermine, O. ALS Clinical Trials Review: 20 Years of Failure. Are We Any Closer to Registering a New Treatment? Front. Aging Neurosci. 2017, 9, 68. [CrossRef]

106. Sawada, H. Clinical efficacy of edaravone for the treatment of amyotrophic lateral sclerosis. Expert Opin. Pharm. 2017, 18, 735-738. [CrossRef]

107. Scott, A. Drug therapy: On the treatment trail for ALS. Nature 2017, 550, S120-S121. [CrossRef]

108. Trias, E.; Ibarburu, S.; Barreto-Núñez, R.; Babdor, J.; Maciel, T.T.; Guillo, M.; Gros, L.; Dubreuil, P.; Díaz-Amarilla, P.; Cassina, P.; et al. Post-paralysis tyrosine kinase inhibition with masitinib abrogates neuroinflammation and slows disease progression in inherited amyotrophic lateral sclerosis. J. Neuroinflamm. 2016, 13, 177. [CrossRef]

109. Takahashi, N.; Duprez, L.; Grootjans, S.; Cauwels, A.; Nerinckx, W.; DuHadaway, J.B.; Goossens, V.; Roelandt, R.; Van Hauwermeiren, F.; Libert, C.; et al. Necrostatin-1 analogues: Critical issues on the specificity, activity and in vivo use in experimental disease models. Cell Death Dis. 2012, 3, e437. [CrossRef]

110. Re, D.B.; Le Verche, V.; Yu, C.; Amoroso, M.W.; Politi, K.A.; Phani, S.; Ikiz, B.; Hoffmann, L.; Koolen, M.; Nagata, T.; et al. Necroptosis drives motor neuron death in models of both sporadic and familial ALS. Neuron 2014, 81, 1001-1008. [CrossRef]

111. Evans, M.C.; Gaillard, P.J.; de Boer, M.; Appeldoorn, C.; Dorland, R.; Sibson, N.R.; Turner, M.R.; Anthony, D.C.; Stolp, H.B. CNS-targeted glucocorticoid reduces pathology in mouse model of amyotrophic lateral sclerosis. Acta Neuropathol. Commun. 2014, 2, 66. [CrossRef]

112. Tsai, C.-P.; Lin, F.-C.; Lee, J.K.-W.; Lee, C.T.-C. Aspirin use associated with amyotrophic lateral sclerosis: A total population-based case-control study. J. Epidemiol. 2015, 25, 172-177. [CrossRef]

113. Espejo-Porras, F.; Fernández-Ruiz, J.; de Lago, E. Analysis of endocannabinoid receptors and enzymes in the post-mortem motor cortex and spinal cord of amyotrophic lateral sclerosis patients. Amyotroph Lateral Scler. Front. Degener 2018, 19, 377-386. [CrossRef] [PubMed]

114. Moreau, C.; Danel, V.; Devedjian, J.C.; Grolez, G.; Timmerman, K.; Laloux, C.; Petrault, M.; Gouel, F.; Jonneaux, A.; Dutheil, M.; et al. Could Conservative Iron Chelation Lead to Neuroprotection in Amyotrophic Lateral Sclerosis? Antioxid. Redox Signal. 2018, 29, 742-748. [CrossRef] [PubMed]

115. Keefe, K.M.; Sheikh, I.S.; Smith, G.M. Targeting Neurotrophins to Specific Populations of Neurons: NGF, BDNF, and NT-3 and Their Relevance for Treatment of Spinal Cord Injury. Int. J. Mol. Sci. 2017, 18, 548. [CrossRef] [PubMed]

116. Mizuno, T.; Kurotani, T.; Komatsu, Y.; Kawanokuchi, J.; Kato, H.; Mitsuma, N.; Suzumura, A. Neuroprotective role of phosphodiesterase inhibitor ibudilast on neuronal cell death induced by activated microglia. Neuropharmacology 2004, 46, 404-411. [CrossRef] 
117. Alfahad, T.; Nath, A. Retroviruses and amyotrophic lateral sclerosis. Antivir. Res. 2013, 99, $180-187$. [CrossRef]

118. Kovalchuk, M.O.; Heuberger, J.A.A.C.; Sleutjes, B.T.H.M.; Ziagkos, D.; van den Berg, L.H.; Ferguson, T.A.; Franssen, H.; Groeneveld, G.J. Acute Effects of Riluzole and Retigabine on Axonal Excitability in Patients With Amyotrophic Lateral Sclerosis: A Randomized, Double-Blind, Placebo-Controlled, Crossover Trial. Clin. Pharmacol. Ther. 2018, 104, 1136-1145. [CrossRef] [PubMed] 